\title{
Physiological quality of soybean seeds stored after industrial treatments with different chemicals
}

Qualidade fisiológica de sementes de soja armazenadas após tratamentos industriais com diferentes produtos químicos

Calidad fisiológica de semillas de soja almacenadas después de tratamientos industriales con diferentes químicos

Renata Cristiane Pereira

ORCID: https://orcid.org/0000-0002-8718-7191 State University of Maringá, Brazil

E-mail: recristianepereira@gmail.com

Lucas Caiubi Pereira

ORCID: https://orcid.org/0000-0001-5799-6695 State University of Maringá, Brazil

E-mail: lucascaiubi@yahoo.br

Alessandro Lucca Braccini

ORCID: https://orcid.org/0000-0002-6915-4804 State University of Maringá, Brazil

E-mail: albracci@uem.br

Larissa Vinis Correia

ORCID: https://orcid.org/0000-0001-9573-7723 State University of Maringá, Brazil

E-mail: larissa.vinis@gmail.com

Murilo Fuentes Pelloso

ORCID: https://orcid.org/0000-0001-5627-8886 State University of Maringá, Brazil

E-mail: murilof.pelloso@ hotmail.com

Thaisa Cavalieri Matera

ORCID: https://orcid.org/0000-0003-2462-9180 State University of Maringá, Brazil E-mail: thaisamatera@hotmail.com

Breno Gabriel da Silva

ORCID: https://orcid.org/0000-0002-8322-9235

University of São Paulo, Brazil

E-mail: brenogsilva@usp.br

Yana Miranda Borges

ORCID: https://orcid.org/0000-0002-1866-5524 Federal Institute of Education, Science and Technology of Amazonas, Brazil E-mail: borges.yana@gmail.com

Carla Coppo

ORCID: https://orcid.org/0000-0001-5225-9813 State University of Maringá, Brazil

E-mail: engagrocarlacoppo@gmail.com

Rayssa Fernanda dos Santos

ORCID: https://orcid.org/0000-0002-6475-8393

State University of Maringá, Brazil E-mail:pg53835@uem.br

\begin{abstract}
This study aimed to relate the smallest set of variables that compose the quality of soybean seeds lot under study, as well as to evaluate the influence of four industrial seed treatments and their respective slurry volumes on the physiological potential. The experiment was carried out in a completely randomized block design with 4 replicates and 24 treatments. The chemical treatments were: control (T1), micronutrient + polymer + drying powder (T2), bioregulator + polymer + drying powder $(\mathrm{T} 3)$ and micronutrient + bioregulator + polymer + drying powder $(\mathrm{T} 4)$. The seeds were stored for periods of $0,15,30,45,60$ and 90 days and were subsequently evaluated for their physiological potential. In each storage period, the variable germination, first count, accelerated aging, emergence speed index, final emergence in the sand substrate, aerial part length, root length and total seedling length were evaluated. The main
\end{abstract}


components of the standard germination test and first count were the ones that most contributed to explaining the variability of the original data. Increasing the volume of the slurry in the industrial seed treatment reduces the physiological quality of soybean seeds during storage.

Keywords: Deterioration; Germination; Glycine max (L); Principal component analysis; Slurry volume.

\section{Resumo}

Este trabalho teve como objetivo relacionar o menor conjunto de variáveis que compõem a qualidade do lote de sementes de soja em estudo, bem como avaliar a influência de quatro tratamentos industriais de sementes e seus respectivos volumes de dejetos no potencial fisiológico. O experimento foi conduzido em delineamento de blocos inteiramente casualizados com 4 repetições e 24 tratamentos. Os tratamentos químicos foram: controle (T1), micronutriente + polímero + pó secante $(\mathrm{T} 2)$, bioregulador + polímero + pó secante (T3) e micronutriente + bioregulador + polímero + pó secante (T4). As sementes foram armazenadas por períodos de 0, 15, 30, 45, 60 e 90 dias e posteriormente avaliadas quanto ao seu potencial fisiológico. Em cada período de armazenamento foram avaliadas as variáveis germinação, primeira contagem, envelhecimento acelerado, índice de velocidade de emergência, emergência final no substrato areia, comprimento da parte aérea, comprimento da raiz e comprimento total da muda. Os principais componentes do teste padrão de germinação e primeira contagem foram os que mais contribuíram para explicar a variabilidade dos dados originais. O aumento do volume da lama no tratamento industrial de sementes reduz a qualidade fisiológica das sementes de soja durante o armazenamento.

Palavras-chave: Deterioração; Germinação; Glycine $\max (L)$; Análise de componentes principais; Volume de pasta.

\section{Resumen}

Este estudio tuvo como objetivo relacionar el menor conjunto de variables que componen la calidad del lote de semilla de soja en estudio, así como evaluar la influencia de cuatro tratamientos industriales de semillas y sus respectivos volúmenes de estiércol sobre el potencial fisiológico. El experimento se realizó en un diseño de bloques completamente al azar con 4 repeticiones y 24 tratamientos. Los tratamientos químicos fueron: control (T1), micronutriente + polímero + polvo secante $(\mathrm{T} 2)$, biorregulador + polímero + polvo secante $(\mathrm{T} 3)$ y micronutriente + biorregulador + polímero + polvo secante (T4). Las semillas se almacenaron por períodos de 0, 15, 30, 45, 60 y 90 días y luego se evaluaron por su potencial fisiológico. En cada período de almacenamiento se evaluaron las siguientes variables: germinación, primer conteo, envejecimiento acelerado, índice de velocidad de emergencia, emergencia final en el sustrato arenoso, longitud de brote, longitud de raíz y longitud total de plántula. Los principales componentes del patrón de germinación y primer recuento fueron los que más contribuyeron a explicar la variabilidad de los datos originales. El aumento del volumen de lodos en el tratamiento industrial de semillas reduce la calidad fisiológica de las semillas de soja durante el almacenamiento.

Palabras clave: Deterioro; Germinación; Glicina máx. (L); Análisis de componentes principales; Volumen de la carpeta.

\section{Introduction}

Ensuring the quality of a seed lot is essential to obtain high productivity since it provides producers with security regarding the physical, sanitary, genetic, and physiological attributes of the seeds. In the field, however, the seeds are exposed to numerous phytosanitary threats, demanding, therefore, the use of chemically treated seeds, to guarantee the maximum physiological potential in the field (França-Neto et al. 2015).

In soybean culture, although widely used in on-farm treatment, the use of cobalt and molybdenum in industrial seed treatment (IST) is still incipiently employed. Both micronutrients are indispensable for success in the biological fixation of atmospheric nitrogen, a process carried out by bacteria of the genus Bradyrhizobium spp., when in symbiosis with soybean culture (Sfredo \& Oliveira, 2010).

Besides the addition of micronutrients and biostimulant growth products have also been added to soybean seed treatment mixes, with a report of beneficial effect on plant physiology and the increase in the number of flowers and roots (Klahold et al. 2006). However, the high volume of slurry used in the IST has been reported to be able to accentuate the deleterious effects of the seed deterioration process, especially during storage (França-Neto et al. 2015).

The physiological potential of the seeds can be defined through laboratory analysis after sowing or during storage. In this context, routine analyzes and vigor tests make it possible to compare the quality of seeds, to determine the potential of the 
seeds submitted to chemical treatments and storage conditions (Marcos Filho, 2015a; Pereira et al. 2020), as well as to identify the lots with superior performance during the storage period and in the field (Guedes et al. 2009).

However, it is important to emphasize that the observation of variables with high correlation must reproduce the quality of the lot and consistently identify the maximum potential of the plants in the field (Johnson and Wichern, 2007). In this sense, the principal component analysis proposes the overlap elimination, identifying the relationship between the information extracted from the data. Thus, there is a need for studies focused on understanding the interrelationship of variables used in tests applied in seed analysis.

Within this context, the hypothesis established is that the physiological quality of seed lots, established by laboratory tests, can be explained by variables with high and low variability among themselves. Given the above, the objective of this study was to identify and relate the most relevant set of tests for the analysis of the physiological quality of treated and stored soybean seeds, depending on the composition of the slurry and storage periods.

\section{Methodology}

This quantitative research is characterized by the use of quantification, both in the collection as in the treatment of information, using statistical techniques (Richardson, 1999; Pereira et al. 2018). The experiment was conducted in 2019 at the Seed Technology Laboratory, located at the Research Center Applied to Agriculture (NUPAGRI) belonging to the State University of Maringá (UEM), in Maringá, Northwest of Paraná State, Brazil.

For each treatment, $2.5 \mathrm{~kg}$ of seeds of the soybean cultivar BMX Alvo RR was used. The IST was performed in a continuous seed coating device, which was subsequently placed in kraft paper bags and maintained in laboratory environmental conditions. The test was conducted in a completely randomized block design, with 4 replicates and 24 treatments, so that the seeds were subjected to combinations of the following products: micronutrient (M) (cobalt and molybdenum - CoMo Platinum ${ }^{\circledR}$, dose: $200 \mathrm{~mL} 100 \mathrm{~kg}^{-1}$ seeds), bioregulator (B) (kinetine, gibberellic acid, and 4-indole3ilbutyric Acid - stimulate ${ }^{2}$, dose: $500 \mathrm{~mL} 100 \mathrm{~kg}^{-1}$ seeds), polymer (POL) (Disco Ag Green, dose: $100 \mathrm{~mL} 100 \mathrm{~kg}{ }^{-1}$ of seeds)

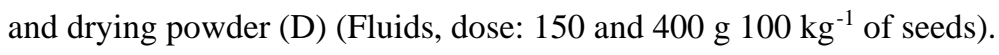

Thus, each seed treatment was defined as follows: untreated control (untreated seeds) (T1), micronutrient + polymer + drying powder (T2), bioregulator + polymer + drying powder $(\mathrm{T} 3)$, and micronutrient + bioregulator + polymer + drying powder (T4), in which each IST received a specific slurry volume of $0,400,700$, and $900 \mathrm{~mL} 100 \mathrm{~kg}^{-1}$ of seeds, respectively. For each treatment, evaluations were performed before and after the periods of 0, 15, 30, 45, 60, and 90 days. Regarding the treatment and storage of seeds, they were submitted to two different conditions, so that part of the seeds were treated and later stored, and after this, tests and evaluations were installed. The rest of the seeds were stored and treated on the day of test installation. The evaluation of the physiological potential of the seeds was performed for each of the storage periods.

The physiological quality of the seeds was evaluated using the following tests: standard germination test (SGT) and first germination count (FC) (Brazil, 2009), accelerated aging (AA) (Marcos-Filho, 1999), emergence speed index (ESI) (Nakagawa, 1994), final emergency in the sand substrate (ES) (Nakagawa, 1994), and seedling growth tests as aerial part length (AL), root length (RL), and total seedling length (SL), according to the method described by Abati et al. (2014).

The data obtained were tested for normality through the Shapiro-Wilk test. To verify significant differences among treatments and among storage periods, the Scott-Knott test was used. The t-Student test was applied to verify significant differences between the treatment periods, and for the analysis of the main components, the relationship structure of the variables was identified with the various combinations of IST. The significance level of 5\% was considered in all tests. Data were analyzed using software R, version 4.0.2 (R Core Team, 2020). 


\section{Results and Discussion}

The analysis of variance indicated a significant difference $(\mathrm{p} \leq 0.05)$ between the evaluated treatments and storage periods. In Table 1, the variables show significant differences between before and after storage (p < 0.05), except for the variables AL and AA.

Table 1. Variables averages comparison under study considering before and after the IST.

\begin{tabular}{cccc}
\hline \multirow{2}{*}{ Variable Response } & \multicolumn{2}{c}{ Time } & p-value \\
\cline { 2 - 3 } & Before Storage & After Storage & 0.65 \\
AL & $6.62 \mathrm{a}$ & $6.53 \mathrm{a}$ & $0.03^{*}$ \\
SL & $19.96 \mathrm{a}$ & $18.77 \mathrm{~b}$ & $0.01^{*}$ \\
RL & $13.33 \mathrm{a}$ & $12.26 \mathrm{~b}$ & $<0.05^{*}$ \\
SGT & $89.70 \mathrm{a}$ & $84.68 \mathrm{~b}$ & $<0.05^{*}$ \\
ESI & $9.20 \mathrm{a}$ & $3.90 \mathrm{~b}$ & $<0.05^{*}$ \\
ES & $78.70 \mathrm{a}$ & $57.90 \mathrm{~b}$ & $<0.05^{*}$ \\
FC & $132.45 \mathrm{a}$ & $88.92 \mathrm{a}$ & 0.23 \\
AA & $124.46 \mathrm{a}$ & $118.32 \mathrm{a}$ & \\
\hline
\end{tabular}

Average followed by distinct letters on the lines differ from each other by the Scott-Knott test; * p-value considered significant ( $\mathrm{p}<0.05$ ). $\mathrm{AL}=$ aerial part length; $\mathrm{SL}=$ total seedling length; $\mathrm{RL}=$ root length; $\mathrm{SGT}=$ standard germination test $; \mathrm{ESI}=$ emergence speed index; $\mathrm{ES}=$ final emergency in the sandsubstrate; $\mathrm{FC}=$ first germination count; and AA = accelerated aging test. Source: Authors.

Table 2 shows the multiple comparisons for each response variable, depending on the storage periods. Thus, it was found that there were significant differences among the storage periods for all the characteristics assessed ( $p<0.05)$, except for the ES between the periods 0 and 15 days (Table 2).

Table 2. Multiple comparisons between seed storage periods.

\begin{tabular}{ccccccc}
\hline \multirow{2}{*}{ Variables } & \multicolumn{7}{c}{ Storage Period (days) } \\
\cline { 2 - 6 } & 0 & 15 & 30 & 45 & 60 & 90 \\
\cline { 2 - 6 } AL & $8.43 \mathrm{a}$ & $7.56 \mathrm{~b}$ & $6.67 \mathrm{c}$ & $6.22 \mathrm{~d}$ & $5.73 \mathrm{e}$ & $4.84 \mathrm{f}$ \\
SL & $24.76 \mathrm{a}$ & $22.29 \mathrm{~b}$ & $19.85 \mathrm{c}$ & $18.56 \mathrm{~d}$ & $16.70 \mathrm{e}$ & $13.98 \mathrm{f}$ \\
RL & $16.76 \mathrm{a}$ & $14.87 \mathrm{~b}$ & $13.48 \mathrm{c}$ & $12.11 \mathrm{~d}$ & $10.80 \mathrm{e}$ & $8.75 \mathrm{f}$ \\
SGT & $97.62 \mathrm{a}$ & $94.06 \mathrm{~b}$ & $90.37 \mathrm{c}$ & $86.68 \mathrm{~d}$ & $82.06 \mathrm{e}$ & $72.18 \mathrm{f}$ \\
ESI & $10.71 \mathrm{a}$ & $9.37 \mathrm{~b}$ & $7.68 \mathrm{c}$ & $5.66 \mathrm{~d}$ & $4.07 \mathrm{e}$ & $2.00 \mathrm{f}$ \\
ES & $98.75 \mathrm{a}$ & $93.12 \mathrm{a}$ & $84.87 \mathrm{~b}$ & $64.00 \mathrm{c}$ & $46.12 \mathrm{~d}$ & $22.31 \mathrm{e}$ \\
FC & $148.37 \mathrm{a}$ & $132.00 \mathrm{~b}$ & $118.00 \mathrm{c}$ & $105.63 \mathrm{~d}$ & $90.50 \mathrm{e}$ & $71.00 \mathrm{f}$ \\
AA & $68.25 \mathrm{a}$ & $52.56 \mathrm{~b}$ & $40.37 \mathrm{c}$ & $29.81 \mathrm{~d}$ & $19.81 \mathrm{e}$ & $7.00 \mathrm{f}$ \\
\hline
\end{tabular}

* Average followed by the same letter on the line do not differ by the Scott-Knott test at 5\% significance. Source: Authors.

The treatment of soybean seeds performed before sowing with different combinations of chemicals and slurry volumes can provide a phytotoxic effect on seedlings (Brzezinski et al. 2015). Despite the decrease in germination, seed storage for up to 60 days (Table 2) did not compromise the potential for seed commercialization, since in SGT the average values of normal seedlings are above $80 \%$, a level established as a minimum guarantee for the commercialization of seed lots in Brazil (Brazil, 2013). In this context, Smaniotto et al. (2014) suggested that the humidity resulting from the IST favored deterioration, especially during storage. In this same perspective, Zorato \& Henning, (2001) pointed out that after 90 days of storage, loss of seed quality was inevitable. In Table 3, it was found that treatment T1 showed superior results about the others, for all response variables, except for ES, in which treatments T1 and T2 did not differ statistically from each other, however, they surpassed the others. 
Table 3. Multiple comparisons between treatments.

\begin{tabular}{ccccc}
\hline \multirow{2}{*}{ Variables } & \multicolumn{4}{c}{ Treatments } \\
\cline { 2 - 5 } & T1 & T2 & T3 & T4 \\
\cline { 2 - 5 } & $8.11 \mathrm{a}$ & $7.00 \mathrm{~b}$ & $6.06 \mathrm{c}$ & $5.13 \mathrm{~d}$ \\
AL & $23.71 \mathrm{a}$ & $20.89 \mathrm{~b}$ & $17.68 \mathrm{c}$ & $15.15 \mathrm{~d}$ \\
SL & $15.97 \mathrm{a}$ & $14.10 \mathrm{~b}$ & $11.40 \mathrm{c}$ & $9.71 \mathrm{~d}$ \\
RL & $95.83 \mathrm{a}$ & $92.20 \mathrm{~b}$ & $83.75 \mathrm{c}$ & $76.87 \mathrm{~d}$ \\
SGT & $10.20 \mathrm{a}$ & $8.30 \mathrm{~b}$ & $4.49 \mathrm{c}$ & $3.33 \mathrm{~d}$ \\
ESI & $95.66 \mathrm{a}$ & $88.83 \mathrm{a}$ & $50.50 \mathrm{~b}$ & $37.79 \mathrm{c}$ \\
ES & $141.66 \mathrm{a}$ & $123.91 \mathrm{~b}$ & $99.50 \mathrm{c}$ & $78.58 \mathrm{~d}$ \\
FC & $62.16 \mathrm{a}$ & $45.29 \mathrm{~b}$ & $25.58 \mathrm{c}$ & $12.16 \mathrm{~d}$ \\
AA &
\end{tabular}

* Averages followed by the same letter on the line do not differ from each other by Scott-Knott's 5\% significance test. Source: Authors.

In this regard, Taylor \& Salanenka, (2012) pointed out that, unlike paper tests, in the emergency sand test (ES), the components of the slurries were diluted in the substrate, thus increasing the sensitivity of the seeds, especially in high vigor seeds. Associated with seed treatment, various products such as biostimulants, micronutrients, and polymers provide increased productivity (Klahold et al. 2006). However, Brzezinski et al. (2017) observed that the high volume of slurry, associated with long periods of storage, harmed seed quality. In the case of soybeans, the presence of a micropyle favored the permeability of the membranes, so that during germination, the chemical in contact with the root caused phytotoxicity and compromised the development of the roots (Peske \& Peske, 2011).

Regarding the correlation analysis among the variables responses, it was found that all are strong and positive, showing that these variables have good properties to be part of the analysis of main components. Table 4 shows the percentage of the total variability explained by each factor and the accumulated percentage. When observing the first factor, it corresponds to about $87.43 \%$ of the total variance, with the first two factors reaching about $92.36 \%$ of the total variance; in these circumstances, main component 1 was responsible for $87.43 \%$ and main component 2 was responsible for $4.92 \%$ of the data variations.

Table 4. Auto values and explanation of total variance.

\begin{tabular}{cccc}
\hline Factor & Auto value & Proportion & Accumulated \\
\hline 1 & 6.99 & 87.43 & 87.43 \\
2 & 2.39 & 4.92 & 92.36 \\
3 & 0.23 & 2.98 & 95.34 \\
4 & 0.13 & 1.72 & 97.07 \\
5 & 0.09 & 1.21 & 98.28 \\
6 & 0.07 & 0.94 & 99.22 \\
7 & 0.03 & 0.41 & 99.63 \\
8 & 0.02 & 0.36 & 100.00 \\
\hline
\end{tabular}

Source: Authors.

Thus, if two factors are selected, the reduction in size from eight original variables to two factors is considered satisfactory. Therefore, only the first two factors were used for the composition of equations (1) and (2).

$$
\begin{aligned}
& \text { Factor } 1=0.26 S G T+0.16 F C+0,25 A A+0,09 E S I+0.90 E S+0.02 A L+0.91 S L+0.07 R L \\
& \text { Factor } 2=0.53 S G T+0.32 F C+0.62 A A+0.02 E S I-0.42 E S+0.05 A L+0.15 S L+0.11 R L
\end{aligned}
$$


In equation (1), referring to the first factor, the variables ES and SL were highlighted, being called final emergency factor in sand and total length of seedling as the factors that most report to each other, confirming the results observed by Vanzolini et al. (2007), in which lots with a high percentage of normal seedlings tend to present satisfactory performance regarding the emergence in the sand. In this respect, Brzezinski et al. (2017) suggested that seeds from high vigor lots had the same tendency to present a high percentage of ES and SL. On the other hand, these factors show that they are negatively correlated with the others, especially with RL and AL, which presented non-expressive relationships and marked discrepancy with the other variables. Regarding equation (2), referring to the second factor, the variables SGT and AA were highlighted, which can be called the contrast factor of the Standard Germination and Accelerated Aging Test (Table 5).

Table 5. Correlation and weighting coefficients of the first two factors.

\begin{tabular}{lllll}
\hline & Correlations & & \multicolumn{2}{l}{ Weighting Coefficient } \\
\hline Variables & Factor 1 & Factor 2 & Factor 1 & Factor 2 \\
\hline SGT & 0.88 & 0.33 & 0.26 & 0.53 \\
FC & 0.96 & -0.05 & 0.16 & 0.32 \\
AA & 0.95 & -0.06 & 0.25 & 0.62 \\
ESI & 0.95 & 0.13 & 0.09 & 0.02 \\
ES & 0.91 & 0.29 & 0.90 & -0.42 \\
AL & 0.89 & -0.37 & 0.02 & 0.05 \\
SL & 0.96 & -0.19 & 0.91 & 0.15 \\
RL & 0.97 & -0.07 & 0.07 & 0.11 \\
\hline
\end{tabular}

Source: Authors.

Such results suggest that these variables explain most of the total variation, conferring the existence of a high correlation between SGT and AA. In this same perspective, Schuab et al. (2006), when assessing the physiological quality of soybean genotypes, observed high correlation values between the AA, SGT, and FC test. On the other hand, the results obtained for ESI and AA indicated a negative correlation among different soybean genotypes studied.

To determine the number of retained factors, it was found that as the first two factors generated from this analysis have eigenvalues $>1(\lambda i>1)$ (Kaiser, 1958; Fraga et al. 2015) and were responsible for $92.36 \%$ of the total variance in the data set, the first two factors were retained. To verify the importance of each variable in the construction of the two factors, the correlations between the original variables and the main components and their weighting coefficients were calculated (Table $5)$.

In this sense, it is important to highlight that, during the aging process, the germinative capacity and the physiological potential of the seeds are affected, so that it starts with the production of free radicals and lipid peroxidation and culminates in disorders of the membrane and tissue death (Marcos Filho, 2015b). Considering equations (1) and (2), there are highly expressive relationships of the seed lot, mainly on the influence of ES and SL by Factor 1. In this perspective, it is known that the analysis of main components helps to understand the information about the studied variables, so that the least possible loss of information from the database under study is sought.

\section{Conclusion}

The increase in the volume of slurry reduced the physiological quality of the seeds during all storage periods. It is important to highlight that the seed treatment directly affects the physiological potential, so that the vigour and viability of the 
seeds become compromised with the increase of products added to the slurry, especially when it comes to repeating the seeds stored after the industrial treatment.

\section{References}

Abati, J., Zucareli, C., Foloni, J. S. S., Henning, F. A., Brzezinski, C. R., \& Henning, A.A. (2014) Treatment with fungicides and insecticides on the physiological quality and health of wheat seeds. Journal of Seed Science. 36(4):392-398.

Brazil (2013): Ministry of Agriculture, Livestock and Supply. Normative Instruction MAPA 45/2013. Official journal of the federal government of Brazil, Executive Branch, Brasília, DF, 22p.

Brazil (2009): Rules for seed analysis. Ministry of Agriculture, Livestock and Supply. Secretaria of Agricultural Defense. Brasília, DF: Mapa/ACS. 395p.

Brzezinski, C. R., Abati J, Henning, F. A., Henning, A. A., França-Neto, J. B., Krzyzanowski, F. C., \& Zucareli, C. (2017) Spray volumes in the industrial treatment on the physiological quality of soybean seeds with different levels of vigor. Journal of Seed Science. 39(2):174-181.

Brzezinski, C. R., Henning, A. A., Abati, J., Henning, F. A., França-Neto, J. B., Krzyzanowski, F.C., \& Zucareli, C. (2015) Seeds treatment times in the establishment and yield performance of soybean crops. Journal of Seed Science. 37(2):147-153.

Fraga, A. B., Silva, F., Hongyu, K., Santos, D. D. S., Murphy, T. W., \& Lopes, F.B. (2015) Multivariate analysis to evaluate genetic groups and production traits of crossbred Holstein $\times$ Zebu cows. Trop Anim Health Prod. 48:533-538.

França-Neto, J. B., Henning, A. A., Krzyzanowski, F. C., Henning, F. A., \& Lorini, I. (2015) Adoption of industrial souybean seed treatment in Brazil 2014/15 harvest. In: Annals VII Brazilian Soybean Congress. Santa Catarina, Brazil, 07-15:360.

Guedes, R. S., Alves, E. U., Gonçalves, E. P., Viana, J. S., Medeiros, M. S., \& Lima, C. R. (2009) Seedling length test in the evaluation of the physiological quality of Erythrina velutina Willd seeds. Semina: Ciências Agrárias 30(4):793-802.

Johnson, R., \& Wichern, D. (2007). Applied Multivariate Statistical Analysis. New Jersey: Prentice Hall.

Kaiser, H. F. (1958). The varimax criterion for analytic rotation in factor analysis. Psychometrika 23:187-200.

Klahold, C. A., Guimarães, V. F., Echer, M. M., Klahold, A., Contiero, R. L., \& Becker, A. (2006). Soybean (Glycine max (L.) Merrill) response to biostimulant action. Acta Scientiarum Agronomy 28(2):179-185.

Marcos-Filho, J. (1999). Accelerated aging test. In: Krzyzanowski, F. C., Vieira, R. D., \& França-Neto, J. B. Seed vigor: concepts and tests. Londrina, PR, Abrates, p.1-24.

Marcos-Filho, J. (2015a). Seed Physiology of Cultivated Plants. Londrina: Abrates, 660p.

Marcos-Filho, J. (2015b). Seed vigor testing: an overview of the past, present and future perspective. Scienti Agricola 72(4), 363-374.

Nakagawa, J. (1994). Vigor tests based on seedling avaluation. In: Vieira R.D., Carvalho, N.M. (Ed.). Seeds vigor tests. Jaboticabal: FUNEP, 48-85.

Pereira, A. S., Shitsuka, D. M., Parreira, F. J., \& Shitsuka, R. (2018). Metodologia da pesquisa científica.

Pereira, R. C., Pelloso, M. F., Correia, L. V., Matera, T. C., Dos Santos, R. F., Braccini, A. L., \& Da Silva, B. G. (2020). Physiological quality of soybean seeds treated with imidacloprid before and after storage. Plant, Soil and Environment, 66(10), 513-518.

Peske, S. T., \& Peske, F. B. (2011) Water absorption under stress. Seed News, ano XV, n.3.

R Core Team. (2020). R: a language and environment for statistical computing. Vienna, AT: R Foundation for Statistical Computing.

Richardson, R. J. (1999). Pesquisa social: métodos e técnicas. São Paulo: Atlas.

Schuab, S. R. P., Braccini, A. L., França-neto, J. B., Scapim, C. A., \& Meschede, D. K. (2006). Soybean physiological seed potential and the relationship with seedlings emergence in field. Acta Scientiarum Agronomy. 28:553-561.

Sfredo, G. J., \& Oliveira, M. C. N. (2010) Soybean: molybdenum and cobalt. Londrina: Embrapa Soja (Documents, 322 ).

Smaniotto, T. A. S., Resende, O., Marçal, K. A. F., Oliveira, D. E. C., \& Simon, G. A. (2014) Physiological quality of soybean seeds stored in different conditions. Revista Brasileira de Engenharia Agrícola Ambiental 18(4), 446-453.

Taylor, A. G., \& Salanenka, Y. A. (2012). Seed treatments: phytotoxicity amelioration and tracer uptake. Seed Science Research 22, 86-90.

Vanzolini, S., Araki, C. A. S., Silva, A. C. M. T., \& Nakagawa, J. (2007). Seedling length test in the evaluation of the physiological quality of soybean seeds. Revista Brasileira de Sementes. 29:90-96.

Zorato, M. F., \& Henning, A. A. (2001). Influence of early fungicide treatments, applied at different times of storage, on the quality of soybeans. Brazilian Journal of Seeds, 23(2), 236-244. 